Horsley, N. P., and M. P. Ward. 2021. Why is the Common Grackle becoming less common? Avian Conservation and Ecology 16(2):7. https://doi. org/10.5751/ACE-01879-160207

Copyright (C) 2021 by the author(s). Published here under license by the Resilience Alliance.

Research Paper

\title{
Why is the Common Grackle becoming less common?
}

\author{
Noah P. Horsley ${ }^{1}$ and Michael P. Ward ${ }^{1,2}$ \\ ${ }^{1}$ University of Illinois at Urbana-Champaign, ${ }^{2}$ Illinois Natural History Survey
}

\begin{abstract}
Despite a generalist life history and a widespread distribution, the Common Grackle (Quiscalus quiscula) has declined by more than 58\% since 1970. In Illinois, where this study was conducted, the current rate of decline is $7.03 \%$ annually. We hypothesized that low reproductive success in intensely agricultural areas is driving population decline. To test this, we quantified the nesting success and post-fledging survival of Common Grackles in central Illinois. Over a 2-year period, we monitored 188 nests and tracked the survival of 53 fledglings. Our estimate for nesting success of 0.622 (95\% CI: 0.549-0.695) was much higher than the literature average of 0.267. Similarly, although post-fledging survival had not been estimated previously for Common Grackles, our estimate of 0.617 (95\% CI: 0.471-0.764) was relatively high compared to that of other songbirds (range: 0.23-0.87). The most important factor influencing these estimates was ordinal date, which had a negative relationship with both nesting success and post-fledging survival. These results suggest that reproductive success is not the primary driver of population decline in Illinois. To expand upon the field portion of our study, we constructed a demographic model and used it to conduct a global sensitivity analysis. In our model, adult survival was the most influential demographic parameter in the context of population change. This study serves as an initial step in understanding the mechanism(s) of decline in the Common Grackle. We recommend additional research on the survival of Common Grackles, particularly in relation to persecution on the wintering grounds and exposure to agricultural chemicals.
\end{abstract}

\section{Pourquoi le Quiscale bronzé devient-il moins commun?}

RÉSUMÉ. Malgré un mode de vie généraliste et une répartition étendue, le nombre de Quiscales bronzés (Quiscalus quiscula) a diminué de plus de $58 \%$ depuis 1970. Dans l'Illinois, où cette étude a été menée, le taux actuel de diminution est de 7,03\% par an. Nous avons émis l'hypothèse voulant que le faible succès de reproduction dans les secteurs d'agriculture intensive soit à l'origine de la baisse de population. Pour vérifier cette hypothèse, nous avons quantifié le succès de nidification et la survie après l'envol du Quiscale bronzé dans le centre de l'Illinois. Sur une période de deux ans, nous avons suivi 188 nids et surveillé la survie de 53 oisillons. Nous avons établi que le succès de nidification était de 0,622 (IC $95 \%$ : 0,549-0,695), valeur beaucoup plus élevée que la moyenne de 0,267 rapportée dans la littérature. De même, bien que la survie après l'envol n'ait pas été calculée auparavant pour le Quiscale bronzé, notre estimation de 0,617 (IC $95 \%$ : 0,471-0,764) était relativement élevée par rapport à celle d'autres oiseaux chanteurs (plage : 0,23-0,87). Le facteur qui a influé le plus sur ces estimations était la date ordinale, qui montrait une relation négative avec le succès de nidification et la survie après l'envol. Ces résultats indiquent que le succès de reproduction n'est pas le principal moteur de la baisse des populations dans l'Illinois. Pour approfondir notre étude au-delà des travaux de terrain, nous avons construit un modèle démographique et l'avons utilisé pour effectuer une analyse de sensibilité globale. Selon notre modèle, la survie des adultes était le paramètre démographique le plus influent dans le contexte de changement advenant au sein des populations. Cette étude constitue une première étape dans la compréhension du ou des mécanismes sous-jacents à la baisse des populations du Quiscale bronzé. Nous recommandons de mener des recherches supplémentaires sur la survie du Quiscale bronzé, notamment en relation avec la persécution sur les sites d'hivernage et l'exposition aux produits chimiques en milieu agricole.

Key Words: agricultural intensification; Common Grackle; common species; nest success; population decline; post-fledging survival

\section{INTRODUCTION}

An increasing number of animals are experiencing population declines, regional extirpation, and extinction as a consequence of mounting anthropogenic pressures. Conservation efforts meant to address this issue frequently focus on preserving biodiversity and disproportionately aid species with a high perceived risk of extinction (Baillie et al. 2004). Generally, these species have a small global population, fill a narrow ecological niche, and/or inhabit a limited geographic range. In North America, this strategy has led to the successful recovery of many once-threatened species (e.g., Peregrine Falcon, Falco peregrinus; Tordoff and Redig 1997;
Brown Pelican, Pelecanus occidentalis; Holm et al. 2003; Blackcapped Vireo, Vireo atricapilla; USFWS 2016). However, although there is clear merit in protecting rare species, overall ecosystem health may be more dependent on the collective services of common species (Gaston 2010). Given the current breadth and pace of environmental change, the risk to many widespread and abundant species is unprecedented (Turner et al. 2007). This is evidenced by the plight of North American avifauna, which declined by $29 \%$, roughly three billion birds, between 1965 and 2015 (Rosenberg et al. 2019). Notably, more than 2 billion of these losses came from just 15 common species (NABCI 2019). During the same period, 33 historically abundant 
species lost half or more of their global population (NABCI 2014). Five species are included in both of these statistics: Blackpoll Warbler (Setophaga striata), Horned Lark (Eremophila alpestris), House Sparrow (Passer domesticus; non-native), Pine Siskin (Spinus pinus), and Common Grackle (Quiscalus quiscula).

The Common Grackle (hereafter grackle) is a large, conspicuous blackbird native to eastern North America. Often associated with open farmland and rural townships, the species is a staple of Midwestern agricultural landscapes and a prominent source of crop damage (DeGrazio 1978). The grackle has several ecological traits that make it well equipped to exploit anthropogenic landscapes, including foraging in flocks, a generalist diet, a widespread geographic distribution, and the ability to breed in disturbed and urban environments (Ridgway 1889, Marzluff et al. 1994). As a result, grackles have endured, and arguably thrived, amid considerable changes in land cover and land use throughout their native range, even demonstrating westward expansion up until the early 1990s (Marzluff et al. 1994). For much of the $20^{\text {th }}$ century, they were one of the most numerous bird species on the continent (Peterjohn et al. 1994). Today, however, the global population of the grackle is a fraction of what it once was. The species has suffered a net decline of $58 \%$ over the last 50 years, and populations in the core of its breeding range (6 states with highest breeding season relative abundance) are declining by $3.62 \%$ per year (Pardieck et al. 2019; Fig. 1). The primary source of grackle decline is unclear; contemporary research is conspicuously lacking for this abundant and accessible blackbird. Studies on other icterids (blackbirds) and farmland birds that share the agricultural landscape with grackles have identified agricultural intensification as a major driver of decline (Donald et al. 2001, Stanton et al. 2018).

Fig. 1. Data from the Breeding Bird Survey (BBS) showing Common Grackle (Quiscalus quiscula) population decline in the core of its breeding range. Population trends in these six states are shown because they are six of the seven states with the highest relative abundance of Common Grackles, according to BBS data. The seventh state, Delaware, was excluded because the mean number of routes per year was exceptionally low. "Average" is the mean number of individuals per route across the six states.

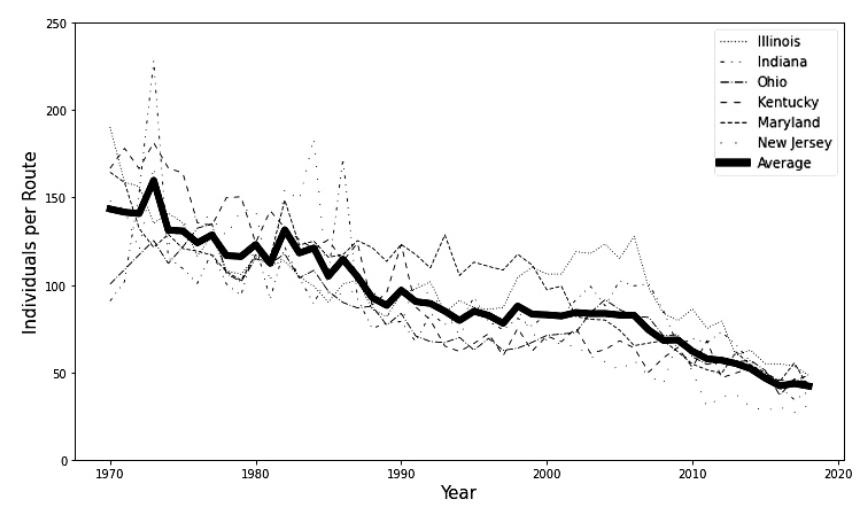

Agricultural intensification, i.e., the homogenization and mechanization of the traditional farm, is a process that began in
North America in the 1960s. The gradual transition from small, mixed-farming systems to large, monoculture farms has increased agricultural outputs at the cost of increased agrochemical inputs and reduced ecological heterogeneity (Benton et al. 2003). Over this period, grassland birds have exhibited more significant and consistent declines than any other guild (Tucker and Heath 1994, Peterjohn and Sauer 1999). In Europe, this trend has been correlated with indices of agricultural intensity (e.g., crop yield, livestock density, and pesticide use; Donald et al. 2006). Ultimately, the mechanism by which a species' population declines is either poor survival or poor reproductive success. Although agricultural intensification (e.g., habitat degradation, agrochemicals) may be a proximate cause, understanding which life stages are driving the decline of a population is critical in the conservation and management of species (Marra et al 2015). We investigated the nesting and post-fledging life stages of grackles and modeled the relative influence of adult survival on grackle population dynamics in an effort to understand how different life stages may explain observed population declines.

One important life stage for avian populations is the nesting period. Poor nest success, i.e., a reduction in the number of young produced from a nest, can lead to population declines (Robinson et al. 1995). Predation is the primary source of nest failure in passerines (Ricklefs 1969) and, in many altered habitats, populations of nest predators have increased in both abundance and diversity (Chalfoun et al 2002). Additionally, in agricultural areas, the removal of natural habitat coupled with an increase in food availability (in the form of spilled grain and other agricultural products) can lead to an increase in mammals that are common nest predators (Chalfoun et al 2002). Consequently, in the fragmented agricultural landscapes where grackles often nest, nest predation risk can be especially high (Vander Haegen et al. 2002). In intensive agricultural areas of Iowa, over $50 \%$ of nests constructed in roadside habitats were lost to predators (Camp and Best 1994) and nest predation was a major factor impacting population growth rates of birds (Fletcher et al. 2006). In Illinois, VanBeek and colleagues (2014) found low nest survival for species breeding in agricultural fields. The impact of nest predation on bird populations breeding in agricultural areas extends to other regions as well. In Britain, poor nesting success is suspected to be the cause of population declines in several farmland species (Newton 2004). These studies in agricultural areas suggest that nesting success may be a vulnerable period in the life cycle of grackles.

Another potentially critical period in the life cycle of birds is the time between when they leave their nest and when they disperse or migrate, known as the post-fledging period (Cox et al. 2014). For many species, the post-fledging period is characterized by high rates of juvenile mortality during the first days after young leave the nest (Cox et al. 2014, Naef-Daenzer and Grüebler 2016). These high rates of mortality are likely the result of juveniles being underdeveloped and limited in their mobility upon leaving the nest, making them susceptible to several sources of post-fledging mortality (Cheng and Martin 2012, Martin 2015, Jones et al. $2020 a$, Jones and Ward 2020). Consequently, the post-fledging period has been referred to as a "survival bottleneck" (NaefDaenzer and Grüebler 2016) in the context of avian population dynamics. Furthermore, life history models suggest that concentrated periods of juvenile mortality, such as in the post- 
fledging period, can drive life history evolution and population dynamics in animal systems (e.g., Law 1979, Reznick et al. 1990, Martin 2004). High rates of post-fledging mortality in an agricultural system could therefore contribute to population declines in species such as the grackle. To our knowledge, however, there remains a paucity of studies of post-fledging survival in agricultural habitats and no studies on grackles.

Avian population dynamics can also be strongly influenced by adult survival. Unfortunately, collecting the quantity and quality of data required to produce robust estimates of adult survival can be challenging in migratory birds (Sillett and Holmes 2002). Regardless, several studies have conducted simulation models to estimate adult survival and its relative influence. In the majority of cases, it is the most influential parameter in predicting population changes (Rushing et al. 2017). For example, Fletcher and colleagues (2006) developed a simulation model to determine the parameters impacting the populations of Dickcissels (Spiza americana) and Bobolinks (Dolichonyx oryzivourus) in an agricultural landscape in Iowa. Although nest survival was important, the model suggested the most sensitive parameter was adult survival.

In this study, we investigated grackle population decline through the lens of three critical life stages: nesting success, post-fledging survival, and adult survival. Specifically, our objectives were to: (1) estimate measures of reproductive success (i.e., clutch size, nest success, post-fledging survival), (2) compare these estimates to estimates from the literature, (3) build a demographic model to simulate population growth, and (4) conduct a global sensitivity analysis to identify which demographic factor (i.e., survival or reproductive success) has the greatest influence on population change. By doing so, we aimed to improve our understanding of the factors contributing to grackle decline and inform future research exploring mechanism(s) of decline among common birds in agricultural landscapes.

\section{METHODS}

\section{Study species}

The grackle is a large, socially monogamous songbird of the family Icteridae. Its breeding range extends west to the Rocky Mountains, east to the Atlantic Ocean, north into the Interior Plains of Canada, and south to the Gulf of Mexico. They frequent fields, pastures, feedlots, farmsteads, drainage ditches, and other open agricultural areas (Erskine 1971). Grackles are not territorial (Ficken 1963, Wiens 1965) and prefer to nest semicolonially in conifers; common breeding sites include farmsteads, shelterbelts, and commercial tree plots (Maxwell 1970). They also nest on bridges and in open woodlands near agriculture or water (Erskine 1971). Accounts of their historical nesting habitats vary; in Arkansas, grackles bred in riparian areas and willow thickets (Howell 1911), whereas in Illinois, "In their choice of location for a nest they are by no means particular..." (Ridgway 1889:327). In Illinois, grackles have been documented nesting in large numbers on Christmas tree farms and nursery plots (Peer and Bollinger 1997, Maddox and Weatherhead 2009).

Grackles migrate north in February and March and begin breeding in early April (Bohlen and Zimmerman 1989), which is earlier than most other songbirds in the region. A breeding pair typically produces a single clutch of four-five eggs (range: onenine). Re-nesting in response to predation and nest parasitism is uncommon but has been observed. Incubation lasts 12-14 days (range: 11-15) and, in larger clutches, eggs hatch asynchronously (Maddox and Weatherhead 2008). Nestlings are brooded and fed primarily by the female and fledge the nest after 12-15 days (range: 10-17; Peer and Bollinger 2020). Adults continue care during the post-fledging period for two to three weeks (Howe 1976).

The grackle is omnivorous, feeding on a combination of invertebrates, grains, wild seeds, fruits, and other edible matter. Among adults, vegetable matter constitutes $70-80 \%$ and animal matter $20-30 \%$ of the annual diet (Beal 1900, Meanley 1971). The composition of the diet changes substantially and predictably throughout the year (Linz et al. 2017). During the breeding season, adults and young feed primarily on invertebrates $(60-65 \%$ of stomach contents in adults, $70-75 \%$ in young; Beal 1900). The rest of the year, the diet shifts to grains and seeds, with fruits, vertebrates, and other edible matter incorporated opportunistically. Crops like corn, rice, oats, sunflowers, and peanuts make up a large part of the grackle diet in the regions in which the growing season overlaps with grackle presence. In rice growing regions in Arkansas, for example, the winter diet can be up to $60 \%$ rice (Meanley 1971).

\section{Study sites}

We sampled our primary study site (Maddox) in 2018 and 2019. Maddox was a rectangular 1-hectare plot southwest of Bondville, Illinois $\left(40^{\circ} 05^{\prime} 35^{\prime \prime} \mathrm{N}, 88^{\circ} 23^{\prime} 16^{\prime \prime} \mathrm{W}\right)$ that was planted with 1000 Scotch Pines (Pinus sylvestris) between 2007 and 2008. At the time of our study, the trees were $2.5-4 \mathrm{~m}$ in height, growing in a tall $(0.75-1.25 \mathrm{~m}) \mathrm{mix}$ of grasses and forbs. The surrounding landscape was a matrix of conventional corn and soybean agriculture, with a small housing development to the north and a drainage ditch running north-south to the west.

We sampled our second study site (Byrd) in 2019 only. Byrd was a rectangular five-hectare farmstead southeast of Philo, Illinois $\left(39^{\circ} 58^{\prime} 04^{\prime \prime} \mathrm{N}, 88^{\circ} 0^{\prime} 33^{\prime \prime} \mathrm{W}\right)$ that was planted with an eastern white pine (Pinus strobus) and blue spruce (Picea pungens) windbreak. At the time of our study, the pine trees were 1.5-5 $\mathrm{m}$ in height and the spruce trees were 2-3 $\mathrm{m}$ in height, growing in a mowed lawn. Byrd also featured a 0.75 -acre pond on the western half of the property and 3.25 acres of row-crop agriculture on the eastern half of the property. The surrounding landscape was a matrix of conventional corn, wheat, and soybean agriculture, with a rural housing development, a small wooded plot, and a free-range cattle pasture to the west and a patch of shrubland habitat to the southeast. The area in which both of these sites are located is dominated by corn and soybeans with $91.5 \%$ of the Champaign County (where these sites were located) being in agriculture (Champaign County Regional Planning Commission 2010)

\section{Nest monitoring}

We conducted nest searches at each site weekly, during which every tree was visually inspected for grackle nests. An active nest was defined as a nest with $\geq 1$ grackle egg. We recorded nest height and location when a nest became active. We checked active nests, at minimum, once every three days until success or failure. When nests approached the predicted fledge date, we increased the frequency of nest checks to once per day. We recorded the number 
Table 1. Candidate model set ranked using Akaike information criterion (AICc) for factors influencing Common Grackle (Quiscalus quiscula) nest success in Champaign County, Illinois during 2018-2019. Note: $\mathrm{K}=$ number of estimated parameters; LL $=$ natural logarithm of the maximum likelihood; $\mathrm{w}_{\mathrm{i}}=$ Akaike weight; $\triangle \mathrm{AICc}=$ difference in AICc (Akaike's information criterion corrected for small sample size) relative to minimum.

\begin{tabular}{|c|c|c|c|c|c|c|}
\hline$\overline{\text { Model }^{\dagger}}$ & $\mathrm{K}$ & $\mathrm{LL}$ & $\triangle \mathrm{AICc}$ & ModelLik & $\mathrm{w}_{\mathrm{i}}$ & Cum. weight \\
\hline Seasonality & 4 & -215.33 & 0.00 & 1.00 & 0.60 & 0.60 \\
\hline Seasonality + Nest Age & 5 & -215.17 & 1.69 & 0.43 & 0.26 & 0.85 \\
\hline Seasonality + Nest Age + Clutch Size & 6 & -214.74 & 2.84 & 0.24 & 0.14 & 1.00 \\
\hline Nest Age & 4 & -223.30 & 15.94 & 0.00 & 0.00 & 1.00 \\
\hline Intercept Only (null) & 1 & -233.43 & 30.19 & 0.00 & 0.00 & 1.00 \\
\hline Clutch Size & 4 & -232.86 & 35.05 & 0.00 & 0.00 & 1.00 \\
\hline
\end{tabular}

${ }^{\dagger}$ All models include year and site as control variables.

Number of days between nest initiation and nest success/failure.

of eggs and nestlings at each visit, as well as any notes about parental behavior or signs of abandonment, starvation, predation, or fledging. When nestlings were developed enough to fledge the nest ( 12 days post-hatching), we banded them with a size 3 USGS metal band and a unique combination of three 5.5$\mathrm{mm}$ plastic coil color bands. We also collected morphometric measurements including weight, taken with a portable electronic scale (g), wing and tail length, taken with a wing rule ( $\mathrm{mm})$, and culmen and tarsus lengths, taken with digital calipers $(\mathrm{mm})$ for each nestling. Handling time was $<5$ minutes per bird. We then returned all nestlings to the nest and continued to monitor the nest daily until all nestlings fledged or the nest failed. We assumed nests found empty around the expected fledging date had fledged unless there were clear signs of nestling mortality. A nest was considered successful if $\geq 1$ nestling fledged the nest. All capturing and handling of grackles was approved under University of Illinois IACUC protocol \#18011 and Bird Banding Lab permit \#23959.

\section{Nest survival}

We estimated daily nest survival using our nest monitoring data and logistic exposure models in Program R (Shaffer 2004, R Core Team 2018). This method uses a generalized linear model with a binomial probability distribution. It also uses a customized logistic link function to account for the uncertainty around predicting the date of nest termination (Zhao and Sun 2018). We created a set of candidate models to investigate factors that influence nest survival. Our covariates of interest were clutch size (eggs per active nest), seasonality (ordinal date of nest initiation), and nest age (days since initiation). We were interested in clutch size because a negative relationship with nest survival could suggest low food availability. We were interested in the influence of seasonality and nest age (age-specific mortality) because both have been shown to influence nest survival in other species (Young 1963, Sperry et al. 2008). Year and site were included in all models as nuisance variables to control for year- or site-specific variation. The nest initiation date for nests found after eggs had been laid or nestlings had hatched was back calculated based on the stage of the nest, egg laying rates, incubation length, and brooding length. We excluded any nests $(n=13)$ from our final analysis for which we were uncertain of the initiation date. The full candidate model set consisted of single variable models, additive models (three to five variables), and a null model; no interaction models were considered to avoid overly complex models, given our sample size (Table 1).
We evaluated the variables impacting nest survival using Akaike information criterion (AICc; Akaike 1998). The top model was the model with the lowest AICc value and models with $\triangle \mathrm{AICc} \leq$ 2 were considered competitive. The relative strength of the top model was evaluated by considering its AIC ranking relative to the null model, the Akaike weight $\left(w_{i}\right)$ of the top and competitive models, and the confidence intervals of any included covariates.

\section{Radio telemetry}

We randomly selected one nestling per nest to receive a radio transmitter at fledging. Transmitters (Lotek, Newmarket, Ontario) weighed $1.2 \mathrm{~g}$ and were attached using the backpack harness method (Raim 1978). Transmitter weight was $<3 \%$ of bird body mass, per Bird Banding Lab protocol (Protocol \#23959). We monitored radio-tagged fledglings using a hand-held Yagi antenna connected to a telemetry receiver (Model R-1000, Communications Specialists Inc., Orange, California). We attempted to locate tagged birds on days 1, 2, 3, 5, and 7 postfledging, and once every three to five days after that in 2018, and daily for days 1-5 post-fledging, and every other day after that in 2019. If detected, we attempted visual confirmation to verify the fledgling's status. Fledglings were tracked until they were confirmed dead or until the transmitter's battery died (typically around 25 days post-fledging).

We complemented hand-held radio-telemetry with automated radio-telemetry systems (ARTS; Ward et al. 2013, 2014) operating on-site. Towers were $10 \mathrm{~m}$ tall and had 6, 3-element Yagi antennas mounted on top, each connected to an autonomous radiotelemetry receiving unit (JDJC Corp., Fisher, Illinois; ARU) mounted in a metal housing near the base. Each tower collected signal strength (in $\mathrm{dB}$ ), pulse width (milliseconds), and noise (in $\mathrm{dB}$ ) every 30-60 seconds for each active transmitter (Celis-Murillo et al. 2017). This yielded $\sim 115,000$ data points per active transmitter per day. At Maddox, we erected one tower in the northeast corner of the plot and another in the southwest corner of the plot. At Byrd, we erected a single tower at a high point along the northern perimeter of the property. Telemetry towers could detect transmitters at a range of up to $\sim 1.5 \mathrm{~km}$ (the detection distance was limited because of the grackles often being on the ground). The goal of collecting telemetry data was to determine the fate of tracked individuals and, if they did die, the age at death and source of mortality. The automated telemetry facet of this research allowed us to determine the last known location of 
Table 2. Model set ranked using Akaike information criterion (AICc) for age structure of Common Grackle (Quiscalus quiscula) postfledging survival in Champaign County, Illinois during 2018-2019.

\begin{tabular}{|c|c|c|c|c|c|c|}
\hline Model $^{\dagger}$ & No. Par & loglik & $\triangle \mathrm{AICc}$ & ModelLik & $\mathrm{w}_{\mathrm{i}}$ & Cum. weight \\
\hline $0-5,6-11,12-20$ & 2 & 157.20 & 0.00 & 1.00 & 0.48 & 0.48 \\
\hline $0,1,2,3 \ldots 20$ (daily) & 2 & 157.61 & 0.41 & 0.82 & 0.39 & 0.86 \\
\hline $0-5,6-20$ & 2 & 160.08 & 2.87 & 0.24 & 0.11 & 0.98 \\
\hline $0,1,2,3,4,5,6-20$ & 2 & 163.61 & 6.41 & 0.04 & 0.02 & 1.00 \\
\hline $0,1,2,3-9,10-20$ & 2 & 166.83 & 9.62 & 0.01 & 0.00 & 1.00 \\
\hline Intercept (null) & 1 & 187.47 & 28.25 & 0.00 & 0.00 & 1.00 \\
\hline
\end{tabular}

${ }^{\dagger}$ All models were built with a linear fit.

tagged birds and the behavior of the signal in the final hours or minutes (Ward et al. 2018, Nawrocki et al. 2019). On several occasions, a tagged fledgling that was not capable of rapid sustained flight rapidly left the area, suggesting predation by a raptor. In other instances, a failing transmitter battery could be observed over time as irregularities in the signal prior to failure. In summary, the automated telemetry data provided additional information to determine the fate of tagged individuals.

\section{Post-fledging survival}

We created known fate models in Program MARK to estimate daily post-fledging survival (White and Burnham 1999). This method requires an encounter history for each fledgling, containing the status (alive or dead) of the individual for each tracking occasion. We made this assumption based on the limited dispersal ability of young fledglings and our confidence in the combination of hand-held and automated telemetry to determine the fate of nearly all individuals. Three individuals were censored from the data because of the unknown fate of the fledgling; the automated telemetry data for these individuals suggest battery failure (i.e., variable pulse width data). To create 20-day (daily intervals) encounter histories for each fledgling, we used handheld telemetry data when such data was available and ARU tower data to fill in any tracking gaps. We chose a 20 -day post-fledging period because fledglings are relatively independent and highly mobile after 2-3 weeks out of the nest and because our guaranteed transmitter battery life was only 21 days.

For each tracking occasion, we assigned fledglings a status of alive, dead, or unknown. Fledglings we were unable to detect using handheld telemetry were tracked and assigned a status based on ARU tower data. At the end of the 20-day tracking period, we assigned fledglings a fate based on their encounter history: survived, failure, or unknown. Survived signified the fledgling survived the full 20-day post-fledging period, as determined by hand and automated telemetry. Failure signified the fledgling died during the 20-day post-fledging period, as determined by locating the bird and confirming death or finding clear signs of depredation in the ARU tower data. Unknown signified it was unclear if the fledgling survived the 20-day post-fledging period; these individuals were thought to be lost as a result of transmitter failure. We excluded three fledglings with unknown fates from the final analysis.

Two criteria were used to guide these determinations of fledgling fate: how many days a fledgling was confirmed alive and the nature of that fledgling's final ARU tower data. The goal was to differentiate dispersal from depredation among fledglings whose fate could not be confirmed. For the first criterion, we chose a cutoff point of 15 days post-fledging based on our observations of grackle fledgling development and activity. After two weeks, fledglings were capable fliers and were moving around the broader landscape with adult flocks. We presumed fledglings could disperse beyond the range of our ARTS after this age. For the second criterion, we looked for signs of depredation in the ARU tower data. Specifically, we looked for transmitter destruction (strong signal followed by no signal at all) or rapid departure from the study site, especially if these events occurred at a time of day that did not make ecological sense (e.g. at night; Nawrocki et al. 2019).

Constructing models to investigate factors that influence postfledging survival was a two-step process (Jones et al. 2017). The first step was to determine the best age structure for our data (Table 2). Fledgling age (number of days post-fledging) is an established predictor of post-fledging survival and must be accounted for prior to modeling other covariates (Cox et al. 2014). We began by running all the age models that estimated daily survival rate (DSR) for each fledgling age. Using these estimates, we created and ranked six age structures and included the topranked age structure in all future models (Table 2). The second step was to model and rank our other covariates: body condition (condition index), nest productivity (number of nestlings fledged), and seasonality (ordinal date at fledging; Table 3). We modeled body condition using an index of the residuals of a linear regression between mass and tarsus length (Vitz and Rodewald 2011, Jones et al. 2017).

\section{Literature comparison}

We used all available studies with records of grackle reproductive success to compile literature estimates for clutch size, brood size, nest productivity, fledge rate, and nest survival. grackles were a popular study species in the 1960 s and 70 s providing a comparison to a time when agricultural intensification was likely lower. We used a weighted (by sample size) one-sample $t$-test with a Bonferroni correction to compare these estimates (averages for the entire study) with estimates from our study. Some estimates from the literature were unclear or incomplete and were excluded. Trautman (1940), Eyer (1954), and Hamel (1974) combined eggs and nestlings, did not publish the sample size, and had incomplete records, respectively; Howe (1977) and Snelling (1968) had unclear and biased estimates of nest survival, respectively. 
Table 3. Candidate model set ranked using Akaike information criterion (AICc) for factors influencing Common Grackle (Quiscalus quiscula) post-fledging survival in Champaign County, Illinois during 2018-2019.

\begin{tabular}{|c|c|c|c|c|c|c|}
\hline Model $^{\dagger}$ & No. Par & loglik & $\triangle \mathrm{AICc}$ & ModelLik & $\mathrm{w}_{\mathrm{i}}$ & Cum. Weight \\
\hline Age + Seasonality + Cond. Index + Nest Prod. & 7 & 142.12 & 0.00 & 1.00 & 0.58 & 0.58 \\
\hline Age + Seasonality + Cond. Index & 6 & 146.39 & 2.23 & 0.33 & 0.19 & 0.77 \\
\hline Age + Seasonality & 5 & 149.36 & 3.17 & 0.21 & 0.12 & 0.89 \\
\hline Age + Condition Index & 5 & 151.45 & 5.26 & 0.07 & 0.04 & 0.94 \\
\hline Age & 4 & 153.94 & 5.71 & 0.06 & 0.03 & 0.97 \\
\hline Age + Nest Productivity & 5 & 152.08 & 5.89 & 0.05 & 0.03 & 1.00 \\
\hline Intercept (null) & 1 & 187.47 & 33.19 & 0.00 & 0.00 & 1.00 \\
\hline
\end{tabular}

${ }^{\dagger}$ All models include year and site as control variables.

\section{Bird Banding Lab data}

One source of data that could be used to help estimate the age distribution of grackles are the archived data from the USGS Bird Banding Lab. We requested and received grackle banding data from the Bird Banding Lab that had been collected between 1960 and 2020, representing the period of our literature review (Smith 2013). Over this time period, there were 17,147 records we could use to investigate the ratio of adults (after second year, ASY, individuals) to juveniles (hatch year and second year, SY, individuals). We used a weighted average because sample size varied annually. Overall, the average percentage of adults in the population was $70.9 \%$ and the average percentage of juveniles was $29.1 \%$.

\section{Predictive modeling: population growth and demography}

We built a demographic model (Oli and Zinner 2001), written in the Python programming language (Sanner 1999), to simulate stochastic population growth in grackles. The purpose of this model was to support a global sensitivity analysis (GSA) similar to work outlined in Aiello-Lammens and Akcakaya (2017), to identify how grackle population growth is influenced by variation in the underlying demographic parameter. Our input parameters for the demographic model were population size, clutch size, fledge rate, post-fledging survival, juvenile survival, adult survival, SY breeding success, and ASY breeding success. We drew from several sources to estimate input parameter values that would accurately simulate growth in Illinois. We used a population size of 2,800,000 grackles, the estimated population size in Illinois as determined from Breeding Bird Survey (BBS) data and models developed by Will et al. (2019). The BBS is a long-term monitoring program that is widely used to assess the status and trajectory of North American bird populations (Pardieck et al. 2019). Clutch size (4.354), fledge rate (0.361), and post-fledging survival (0.617) were taken from the estimates produced by this study. Clutch size and fledge rate were supported by previous studies of grackle reproductive success and post-fledging survival was supported by post-fledging survival studies on related species. We estimated breeding success (the proportion of individuals that breed) for both SYs (0.900) and ASYs (0.950). For juvenile survival (0.560) and adult survival $(0.675)$ estimates, we used return rate studies to determine the minimum annual survival rate. We then used banding records to estimate the proportion of SY to ASY birds and BBS data to determine the annual rate of population decline. We assessed and adjusted our estimates to reflect these values.
We began each simulation by calculating the stable age distribution for the given set of input parameters. Based on banding records, we expected the age distribution to be around $30 \%$ SY birds and $70 \%$ ASY birds at the start of the breeding season. The stable age distribution was then compared with the age distribution observed in historical banding records and, if comparable, used to initiate the model. We used a standard set of population growth formulas in our model.

$$
\begin{aligned}
& \text { Breeding Pairs }= \\
& \left(\left(\text { Breeding Rate }^{\text {sy }} * \text { Count }^{\text {sy }}\right)+\left(\text { Breeding Rate }^{\text {asy }} * \text { Count }^{\text {asy }}\right)\right) / 2 \\
& \text { Count }^{\mathrm{sy}(\mathrm{t}+1)}=\text { Breeding Pairs * Clutch Size * Fledge Rate * } \\
& \text { Fledgling Survival * Juv. Survival } \\
& \text { Count }^{\text {asy }(t+1)}=\left(\text { Count }^{\text {sy(t) }}+\text { Count }^{\text {asy }(t)}\right) * \text { Adult Survival } \\
& \text { Population }^{\mathrm{t}+1}=\text { Count }^{\text {sy(t+1)}}+\text { Count }^{\text {asy }(t+1)}
\end{aligned}
$$

Each model run simulated 40 years of population growth. Annual mean growth was calculated across iterations and compared with trend estimates from the BBS. For our GSA, a sample size of 10,000 iterations was used. We accounted for environmental stochasticity by uniformly randomly sampling from a range $+/$ the standard deviation of the parameter for each year. Standard deviation was estimated based on observed variation when possible and estimated in all other cases. An annotated Jupyter Notebook (python script) is available via GitHub: https://github. com/nphorsley59/Global_Sensitivity_Analysis

Several assumptions were made by our model. Some were likely biologically incorrect, such as the assumption that no re-nesting or double brooding occurred. There is some evidence that grackles will occasionally re-nest or double brood (Maddox and Weatherhead 2009). Similarly, the model assumed that all birds reached sexual maturity at the start of their second year (i.e., oneyear old) and that the breeding adult sex ratio was 1:1. Again, we considered these assumptions to be reasonable (Richter 1983), but there are likely exceptions.

We conducted a GSA by following the methodology outlined in Aiello-Lammens and Akcakaya (2017). Parameter sets were sampled from an uncertainty space of $+/-5 \%$ of the parameter estimate and run through a demographic model. The outcomes were then modeled using a gradient boosting regression algorithm and the relative influence of each parameter was measured. However, in fitting the GSA to the purpose of our study, we made 
Table 4. Summary of the monitoring effort for Common Grackle (Quiscalus quiscula) nests in Champaign County, Illinois from 2018-2019.

\begin{tabular}{|c|c|c|c|c|c|c|c|}
\hline \multirow[b]{2}{*}{ Year } & \multirow[b]{2}{*}{ Site } & \multicolumn{3}{|c|}{ Nests $^{\dagger+}$} & \multicolumn{3}{|c|}{$\operatorname{Eggs}^{\dagger+}$} \\
\hline & & No. ${ }^{\S}$ & Hatched Eggs & Fledged Young & Laid & Hatched & Fledged \\
\hline 2018 & Maddox & 46 & $42(91.3)$ & $32(69.6)$ & 181 & $150(82.9)$ & 97 (53.6) \\
\hline 2019 & Maddox & 43 & $30(69.8)$ & $24(55.8)$ & 189 & $110(58.2)$ & $79(41.8)$ \\
\hline 2019 & Byrd & 99 & $76(76.8)$ & $56(56.6)$ & 430 & $302(70.2)$ & $209(48.6)$ \\
\hline Total & & 188 & $148(78.7)$ & $112(59.6)$ & 800 & $562(70.3)$ & $385(48.1)$ \\
\hline
\end{tabular}

${ }^{\dagger}$ Percentages of No. given in parentheses.

Includes all potential sources of failure.

${ }^{\S}$ Nests with $\geq 1$ eggs.

two methodological changes. First, we chose to use Latin hypercube sampling (LHS) to sample parameter values from the uncertainty space and a sample size (i.e., iterations) of 10,000. And second, we used our previously described demographic model instead of RAMAS software used by Aiello-Lammens and Akcakaya (2017).

\section{RESULTS}

\section{Reproductive success}

We monitored 188 nests across 2 sites in 2018 and 2019 (Table 4). The average clutch size (eggs per active nest) was 4.26 (range 1-6, $\mathrm{SE}=0.07$ ). The average brood size (nestlings per nest in which at least one egg hatched) was 3.80 (range $1-6, \mathrm{SE}=0.09$ ). The average nest productivity (fledglings per successful nest) was 3.43 (range $1-5, \mathrm{SE}=0.10)$. Our results show that successful nests, on average, lost $\sim 1$ egg/nestling (0.83) during the incubation/nestling period. Roughly $40 \%$ of nests failed and the number of fledglings produced per active nest was only $2.05(\mathrm{SE}=0.14)$. Known sources of egg and nestling mortality include predation, starvation, extreme weather, and exposure. Anecdotally, predation was the primary source of nestling mortality. We found a brood abandonment rate of $4 \%$ and a nestling starvation rate (mean number of nestlings that disappeared per successful nest) of 0.36 .

The top ranked model in the analysis of factors that influence nest survival included site, year, and seasonality ( $w_{i}=0.60$; Table 1). Using this model, we estimated a nest daily survival rate (DSR) of 0.982 ( $\mathrm{SE}=0.002 ; 95 \% \mathrm{CI}: 0.977-0.986)$ and a nest survival rate of $0.622(\mathrm{SE}=0.037)$ for the 26-day nesting period. The second ranked model $\left(\triangle \mathrm{AICc}=1.69, w_{i}=0.26\right)$ added nest age to the top model. Despite the second ranked model's high AIC ranking, it was not considered competitive because of collinearity between nest age and seasonality $(r=0.70$; variance inflation factor, VIF < 2). Although site and year were included in the top model, the most biologically meaningful variable is likely seasonality. Nest survival declined throughout the season (Fig. 2).

\section{Post-fledgling survival}

We tagged and tracked 53 fledgling grackles: 19 at Maddox in 2018, 12 at Maddox in 2019, and 22 at Byrd in 2019. With handheld telemetry, average tracking duration was 9.57 ( $\mathrm{SE}=1.07)$ days post-fledging. The addition of ARTS data increased this average to 15.06 days $(\mathrm{SE}=1.09)$. In total, 22 fledglings $(41.5 \%)$ were confirmed alive the entire 20-day tracking period. Another 8 fledglings $(15.1 \%$ ) were confirmed alive for the first 15 days post- fledging and then dispersed from the study site. Of the remaining 23 fledglings, $11(20.1 \%)$ were assumed depredated based on ARU tower data and $12(22.6 \%)$ were confirmed dead. The cause of death in the 12 cases of confirmed mortality was split evenly between predation (6) and exposure (6). We began modeling postfledging survival by constructing and ranking five age structures using estimates from a fully parameterized age model. The best model grouped fledgling ages 0-5, 6-11, and 12-20 days $\left(w_{i}=0.48\right.$; Table 2). A daily age structure was also competitively ranked $\left(\triangle \mathrm{AICc}=0.41, w_{i}=0.39\right)$, but we chose to use the less complex, higher ranked model.

Fig. 2. The negative effect of seasonality on Common Grackle (Quiscalus quiscula) nest survival in central Illinois during spring 2018-2019. Dashed lines represent the upper and lower bounds of the $95 \%$ confidence interval.

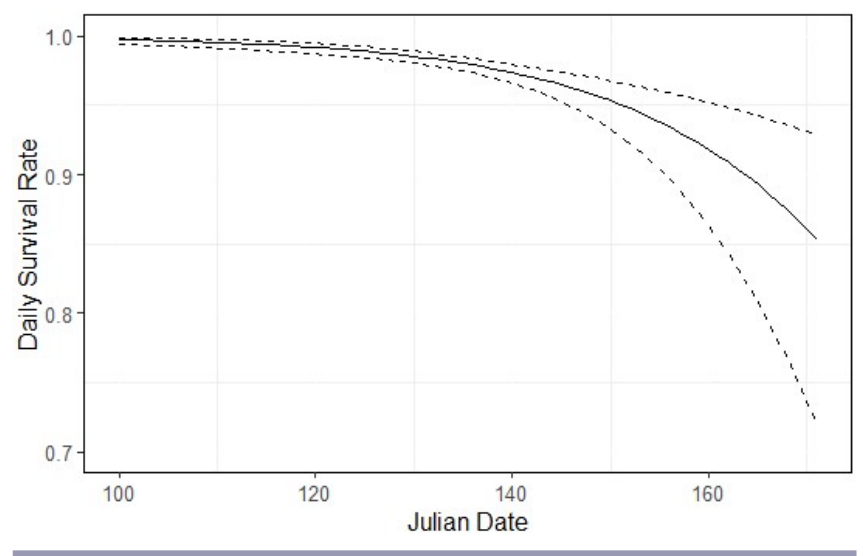

The second step of modeling yielded a top model that included all the covariates we tested (age, seasonality, condition index, and nest productivity; $\mathrm{AICc}=142.12, w_{i}=0.58$; Table 3 ). Using this model, we found a DSR of 0.969 (SE $=0.007,95 \% \mathrm{CI}$ : 0.953-0.980) and a cumulative 20-day post-fledgling survival rate of $0.617(\mathrm{SE}=0.075)$. Age $(\beta=15.83,85 \% \mathrm{CI}$ from 7.67 to 24.00$)$ was the primary predictor of post-fledging survival. Survival increased with fledgling age (Fig. 3); most mortality occurred from ages $0-5$. The covariates seasonality $(\beta=-0.09,85 \% \mathrm{CI}$ from -0.14 to -0.04$)$, condition index $(\beta=-0.52,85 \% \mathrm{CI}$ from -0.91 to -0.14 ), and nest productivity $(\beta=-0.09,85 \%$ CI from -0.16 to -0.02 ) were negatively associated with post-fledging survival but had a smaller influence on survival than age. 
Table 5. Summary of accounts of Common Grackle (Quiscalus quiscula) reproductive success since 1950.

\begin{tabular}{|c|c|c|c|c|c|c|c|c|c|c|}
\hline Author(s) & Year & Location & $\overline{\text { No. }^{\dagger}}$ & Clutch Size & Nestlings $^{*}$ & Nest Prod. ${ }^{\S}$ & $\begin{array}{l}\text { Fledge } \\
\text { Rate }\end{array}$ & $\begin{array}{c}\text { Nest } \\
\text { Success }\end{array}$ & $\begin{array}{c}\mathrm{PF} \\
\text { Survival }\end{array}$ & $\begin{array}{l}\text { Adult } \\
\text { ASR }\end{array}$ \\
\hline Peterson, A. and Young, H. & 1950 & Wisconsin & 62 & 4.87 & 3.37 & $4.00(34)$ & 0.45 & 0.55 & & \\
\hline Wiens & 1965 & Wisconsin & 33 & 4.42 & 3.55 & $3.85(20)$ & 0.53 & 0.61 & & \\
\hline Long, C. A. and Long, C. F. & 1968 & Michigan & 23 & 4.21 & & & & & & \\
\hline Snelling & 1968 & Wisconsin & 47 & 3.98 & 2.64 & $2.87(15)$ & 0.23 & 0.32 & & \\
\hline Jones, H. P. & 1969 & Kentucky & 64 & 4.70 & & & & & & \\
\hline Maxwell & 1970 & Ohio & 18 & 4.30 & & & & & & \\
\hline Erskine & 1971 & North America & 677 & 4.35 & & & & & & \\
\hline Fankhauser & 1971 & United States & 734 & & & & & & & 0.52 \\
\hline Willson, M. F., et al. & 1971 & Illinois & 66 & 4.90 & & & & 0.04 & & \\
\hline $\begin{array}{l}\text { Maxwell, II, G. R. and Putnam, } \\
\text { L. S. }\end{array}$ & 1972 & Ohio & 19 & 4.21 & 2.05 & $2.60(10)$ & 0.33 & 0.53 & & \\
\hline Howe & 1977 & Michigan & 140 & 4.60 & & $3.07(44)$ & 0.21 & & & \\
\hline Howe, H. F. & 1978 & Michigan & 275 & 4.55 & & $3.30(129)$ & 0.34 & & & \\
\hline Peck, G. K. and James, R. D. & 1987 & Ontario & 517 & 4.11 & & & & & & \\
\hline Twedt, D. J. & 2011 & $\begin{array}{l}\text { Louisiana and } \\
\text { Mississippi }\end{array}$ & 169 & 4.05 & & $3.58(24)$ & 0.13 & 0.14 & & \\
\hline Archived Museum Samples & Varied & United States & 93 & 4.65 & & & & & & \\
\hline Literature & 1973 & Varied & 157 & 4.36 & 3.04 & 3.37 & 0.28 & 0.27 & & $0.52^{\pi}$ \\
\hline Our Results & 2019 & Illinois & 188 & 4.26 & 2.99 & 3.43 & 0.48 & 0.62 & 0.61 & \\
\hline \multicolumn{11}{|c|}{$\begin{array}{l}\text { Nests with } \geq 1 \text { Common Grackle eggs. } \\
{ }^{+} \text {Number of nestlings divided by No. } \\
{ }^{8} \text { Number of successful nests in parentheses. } \\
{ }_{\text {|Weighted means. }} \\
{ }^{9} \text { Estimated from recaptures. }\end{array}$} \\
\hline
\end{tabular}

Fig. 3. The cumulative survival rate (solid line) and daily survival rate (DSR; dashed line) over the first 20 days postfledging for Common Grackle (Quiscalus quiscula) fledglings in Champaign County, Illinois during 2018-2019. Standard error is shown as gray shading for cumulative survival.

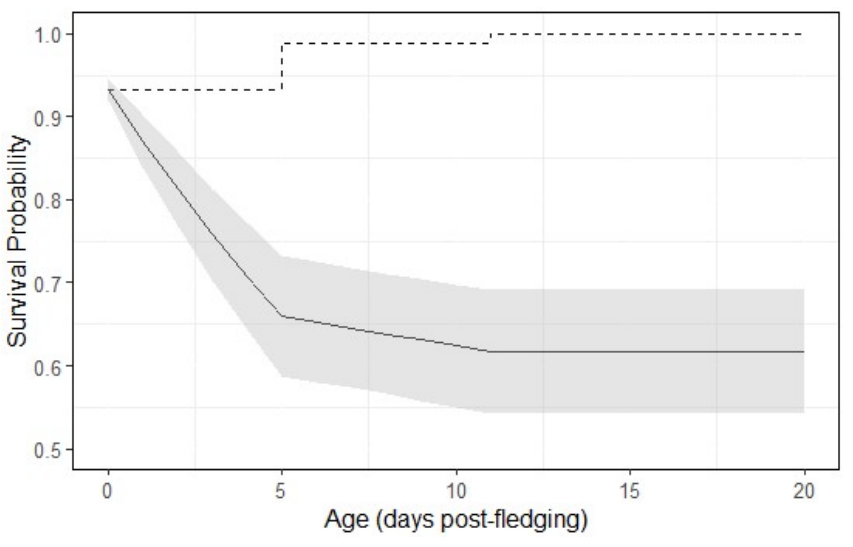

\section{Literature comparison}

We reviewed 17 accounts of grackle reproductive success (Table 5). From this, we derived 14 estimates of clutch size (eggs per nest), 4 estimates of nestlings per total nests, 7 estimates of nest productivity (fledglings per successful nest), 7 estimates of fledge rate (fledglings per total eggs), and 6 estimates (raw or Mayfield's) of nest survival (percentage of nests that fledged $\geq 1$ nestling). Our results were significant or marginally significant for two demographic rates. Fledge rate $(t=-4.38, \mathrm{df}=6, p<0.01)$ and nest survival ( $t=-3.33$, df $=5, p=0.01$ ) were both significantly higher in our study $(0.48,0.62)$ than in the literature $(0.28,0.27)$. For the other three demographic rates, clutch size $(t=1.44, \mathrm{df}=$ $13, p=0.09$; average 4.26), nestlings per total nest $(t=0.16, \mathrm{df}=$ $3, p=0.44$; average $=2.99)$, and nest productivity $(t=-0.45, \mathrm{df}$ $=6, p=0.67$; average $=3.43$ ) were not significantly different from the literature $(4.35,3.04,3.37)$.

\section{Predictive modeling: population growth and demography}

The goal of our demographic modeling and the sensitivity analysis was to determine which parameter(s) had the largest impact on grackle populations. The GSA found adult survival to have the greatest influence on grackle population growth, scoring a relative influence value of 61.55 (this value is out of 100; Fig. $4)$. The next most influential parameter was fledgling survival at 8.63. The simulated data from our demographic model produced an average stable age distribution of $27.3 \%$ SY birds and $72.7 \%$ ASY birds, at a population growth rate of $-7.08 \%$. These values are similar to the age distribution estimated from Bird Banding Lab banding records as well as BBS population growth trends for Illinois between 2005 and 2015.

\section{DISCUSSION}

Overall, the estimates for reproductive success and post-fledging survival from this study were greater than expected given the steep population decline of grackles in Illinois (Sauer et al. 2017). Comparisons of our estimates with those in the past literature suggest that individuals from the study population are reproducing better than other populations sampled decades ago (Table 5). Furthermore, the demographic rates of reproductive 
Fig. 4. Relative influence values from the global sensitivity analysis for each parameter in our demographic model. Relative influence values are ranked on a scale from 0 to 100 .

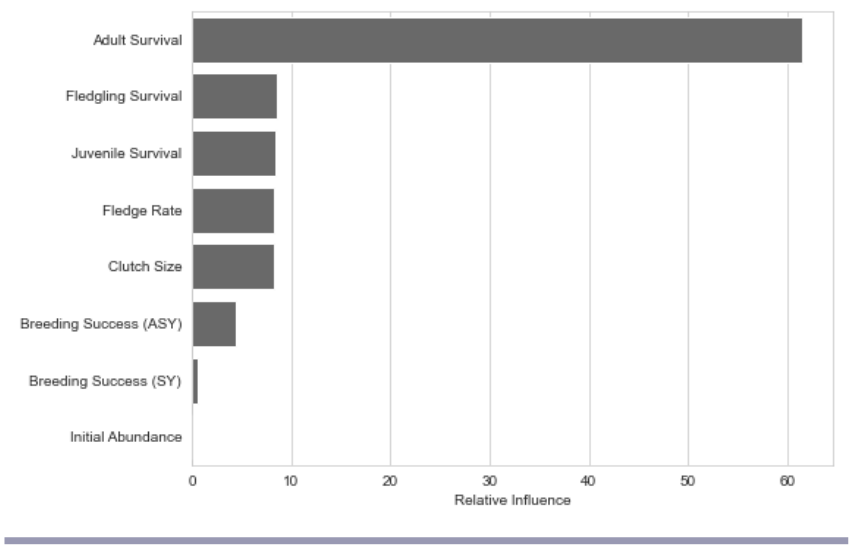

success that we quantified, including nest survival, clutch size, nestlings per total nests, nest productivity, and fledge rate, suggest that net breeding season productivity was high. For example, our estimate of nest survival (62.2\%) was the highest ever recorded and more than double the literature average (27\%), though it should be noted that the nest survival rates in the literature range from 4 to $61 \%$. Additionally, our nest DSR of 0.982 is particularly high when compared to the DSR reported for other songbirds breeding within agricultural fields in Illinois (VanBeek et al 2014). Across 15 grassland and shrubland bird species breeding at natural areas $<50 \mathrm{~km}$ from our study sites, Jones and Ward (2020) found that all but 3 cavity-nesting species (Eastern Bluebird Sialia sialis, Tree Swallow Tachycineta bicolor, and House Wren Troglodytes aedon) had lower DSR than was estimated for grackles in this study.

Although there have been few studies of post-fledging survival in agricultural areas, the survival rate and factors influencing survival (fledgling age) are similar to what has been found in other studies. We found an effect of seasonality on post-fledging survival, with survival declining across the breeding season. The impact of seasonality on post-fledging survival has been documented in other studies (Naef-Daenzer and Grüebler 2016) and, as with nest survival, we expect it is due to increased predator activity (e.g., Sperry et al. 2013). Unlike nest survival, postfledging survival has not been previously studied in the grackle, making it more difficult to evaluate. Our estimate $(61.7 \%)$ is, however, similar to those found in other icterids and appears to be higher than most songbirds in general. For example, in the Eastern Meadowlark (Sturnella magna), a slightly smaller icterid, cumulative post-fledging survival has been estimated at $66-75 \%$ (Kershner et al. 2004, Suedkamp Wells et al. 2007). A recent analysis of post-fledging survival bottleneck suggests that survival of nests and post-fledging in grackles is relatively high compared to other species (Jones et al. 2020b). Overall, it appears that poor post-fledging survival is not low, and as a result, it is unlikely to be leading the species' population decline.

We were unable to directly investigate adult survival in this study and therefore relied on a demographic model in conjunction with a global sensitivity analysis to investigate the relative role of adult survival in the population trajectory of grackles in Illinois. Minimum estimates of grackle survival have been calculated from band recovery data: $49.9 \%$ for males and $53.5 \%$ for females (Fankhauser 1971). However, simulating population growth using the reproductive rate estimates outlined above, which from our estimation appear to be at or above average, yields steep population decline $(-7.08 \%)$ for an adult survival rate of $67.5 \%$ and a juvenile survival rate of $56 \%$. This suggests that juvenile and adult survival must be considerably higher than previously stated to support a stable grackle population in Illinois. Considering that the juvenile and adult survival values used in our simulation were estimates, it is possible that juvenile survival is actually even lower. A large gap in juvenile and adult survival has been observed in other species (Gardali et al. 2003); if true for grackles, it would necessitate even higher rates of adult survival. The global sensitivity analysis suggests that adult survival is the most influential parameter in the population dynamics of grackles. Although similar to past findings in other bird populations (e.g., Fletcher et al. 2006), adult survival is not necessarily the primary factor driving decline (Sæther and Bakke 2000). This is because adult survival is generally much less variable than other parameters. For example, in this study, one of the top models was the effect of year on nesting success, and many studies find wide variation in nesting success across years.

Although this study did not directly address adult and juvenile survival, the fact that we found relatively high rates of reproductive success and post-fledging survival in a steeply declining species suggests adult and/or juvenile survival may be low. We believe it is valuable to point out important factors that differ between grackles and most other songbirds in terms of threats to their survival. As an agricultural pest, grackles have been subject to major population control efforts by the United States government and individual landowners (Heisterberg et al. 1987). Most population control measures for avian pests occur during the non-breeding season. Individuals form large, mixedspecies flocks with other blackbirds and roost in dense colonies, sometimes containing up to 10 million birds (Caccamise et al. 1983). Such dense congregations can be a nuisance, a public health hazard, and a threat to agriculture (Dolbeer et al. 1978). Various strategies, such as roost destruction, harassment, and lethal chemical sprays, are used to control roosting blackbird populations (Heisterberg et al. 1987, Barnes and Constantin 1993). The most aggressive grackle management occurred in Kentucky and Tennessee from 1974-1992, where PA-14 (alphaalkyl[C11-15]-omega-hydroxypoly[oxyethylene]), an avian stressing agent, was used to treat 83 roosts, killing an estimated 38.2 million overwintering blackbirds, $48 \%$ ( 18 million $)$ of which were grackles. In the winter of 1978 alone, an estimated 4.2 million grackles were killed. In 2009, the USDA reported killing or euthanizing over four million blackbirds, roughly double the annual average between 1974-1992 (USDA 2009). Blackbirds may also be killed by private landowners with permission from the US Fish and Wildlife Service or by private landowners acting illegally. If annual adult survival is an important determinant of population growth, direct persecution may be an important driver of population decline in the grackle and warrants additional study.

Grackles are not only facing direct persecution, but their use of agricultural areas also likely exposes them to neonicotinoids (a group of pesticides used to coat seeds of row crops). 
Neonicotinoid seed coatings are water soluble and have high leaching and runoff potential (Morrissey et al. 2015). They pose a significant threat to aquatic invertebrates and have been associated with declines among avian insectivores (Hallmann et al. 2014). Recent field studies in North America also suggest migrating and breeding birds are routinely exposed to neonicotinoids during spring planting (Humann-Guilleminot et al. 2019). Neonicotinoid exposure can have a range of direct and indirect effects on birds, including acute toxicity, impaired migration, reduced fat storage, lethargy, and reduced invertebrate prey availability (Gibbons et al. 2015, Eng et al. 2019). This study was not designed to investigate the impact of neonicotinoids on grackle reproductive success and survival, and therefore we cannot determine the impact of neonicotinoid exposure on grackles. Given the environment in which grackles breed and forage, it is very likely that individuals are exposed to neonicotinoids and controlled experiments are needed to determine the impact of these pesticides on grackles.

Although grackles have experienced significant population decline in the past few decades, they continue to be one of the most common birds in eastern North America. This study, though limited in scope, suggests that the species' nesting success and post-fledging survival are relatively high and that adult survival is a very influential parameter. We believe that more direct research is warranted on the survival of grackles, particularly during the non-breeding season, to determine the parameter(s) driving the decline of this common species.

Responses to this article can be read online at: https://www.ace-eco.org/issues/responses.php/1879

\section{Acknowledgments:}

We thank the Federal Aid in Wildlife Restoration from the Illinois Department of Natural Resources (\#W-154-R) as well as the $U$. S. Fish and Wildlife Service, Region 3 Migratory Bird Program for funding this research. We also recognize Dr. J. Dylan Maddox and the Byrd family for allowing us to work on their property and Dr. Matthew Aiello-Lammens for his counsel on GSA modeling methodology. Finally, we are grateful to our field technicians, Caeley Bryan, Shourjya Majumder, Michael Miller, and Jake Rayapatifor their hard work and attention to detail collecting and entering data.

\section{LITERATURE CITED}

Aiello-Lammens, M. E., and H. R. Akçakaya. 2017. Using global sensitivity analysis of demographic models for ecological impact assessment. Conservation Biology 31:116-125. https://doi. org/10.1111/cobi.12726

Akaike, H. 1998. Information theory and an extension of the maximum likelihood principle. Pages 199-213 in E. Parzen, K. Tanabe, and G. Kitagawa, editors. Selected papers of Hirotugu Akaike. Springer, New York, New York, USA. https://doi. org/10.1007/978-1-4612-1694-0_15
Baillie, J. E. M., C. Hilton-Taylor, and S. N. Stuart. 2004. 2004 IUCN Red List of threatened species: a global species assessment. IUCN, Gland, Switzerland. [online] URL: https://portals.iucn. org/library/node/9830

Barnes, T. G., and B. Constantin. 1993. Managing urban pest bird problems in Kentucky. University of Kentucky, College of Agriculture, Cooperative Extension Service. Lexington, Kentucky, USA.

Beal, F. E. L. 1900. Food of the bobolink, blackbirds, and grackles. United States Department of Agriculture, Division of Biological Survey, Washington D.C., USA. [online] URL: https:// doi.org/10.5962/bhl.title. 62939

Benton, T. G., J. A. Vickery, and J. D. Wilson. 2003. Farmland biodiversity: is habitat heterogeneity the key? Trends in Ecology and Evolution 18:182-188. https://doi.org/10.1016/s0169-5347 (03)00011-9

Bohlen, H. D., and W. Zimmerman. 1989. Birds of Illinois. Indiana University Press, Bloomington, Indiana, USA.

Caccamise, D. F., L. A. Lyon, and J. Fischl. 1983. Seasonal patterns in roosting flocks of starlings and Common Grackles. Condor 85:474-481. https://doi.org/10.2307/1367990

Camp, M., and L. B. Best. 1994. Nest density and nesting success of birds in roadsides adjacent to rowcrop fields. American Midland Naturalist 1:347-358. https://doi.org/10.2307/2426260

Celis-Murillo, A., W. Schelsky, T. J. Benson, M. I. Louder, and M. P. Ward. 2017. Patterns, correlates, and paternity consequences of extraterritorial foray behavior in the field sparrow (Spizella pusilla): an automated telemetry approach. Behavioral Ecology and Sociobiology 71:45. https://doi. org/10.1007/s00265-017-2273-9

Chalfoun, A. D., F. R. Thompson, III, and M. J. Ratnaswamy. 2002. Nest predators and fragmentation: a review and metaanalysis. Conservation Biology 16:306-318. https://doi. org/10.1046/j.1523-1739.2002.00308.x

Champaign County Regional Planning Commission. Champaign County land resource management plan. 2010. Champaign County Regional Planning Commission, Urbana, Illinois, USA. [online] URL: https://ccrpc.org/documents/champaign-countyland-resource-management-plan/

Cheng, Y.-R, and T. E. Martin. 2012. Nest predation risk and growth strategies of passerine species: grow fast or develop traits to escape risk? American Naturalist 180:285-295. https://doi. org/10.1086/667214

Cox, W. A., F. R. Thompson, III, A. S. Cox, and J. Faaborg. 2014. Post-fledging survival in passerine birds and the value of postfledging studies to conservation. Journal of Wildlife Management 78:183-193. https://doi.org/10.1002/jwmg.670

Degrazio, J. W. 1978. World bird damage problems. Proceedings of the vertebrate pest conference (Vol. 8, No. 8). University of Nebraska - Lincoln, Lincoln, Nebraska, USA. [online] URL: https://digitalcommons.unl.edu/vpc8/13

Dolbeer, R. A., P. P. Woronecki, A. R. Stickley, Jr, and S. B. White. 1978. Agricultural impact of a winter population of blackbirds and starlings. Wilson Bulletin 31-44. 
Donald, P. F., R. E. Green, and M. F. Heath. 2001. Agricultural intensification and the collapse of Europe's farmland bird populations. Proceedings of the Royal Society of London. Series B: Biological Sciences 268:25-29. https://doi.org/10.1098/ rspb. 2000.1325

Donald, P. F., F. J. Sanderson, I. J. Burfield, and F. P. J. van Bommel. 2006. Further evidence of continent-wide impacts of agricultural intensification on European farmland birds, 1990-2000. Agriculture, Ecosystems and Environment 116:189-196. https://doi.org/10.1016/j.agee.2006.02.007

Eng, M. L., B. J. M. Stutchbury, and C. A. Morrissey. 2019. A neonicotinoid insecticide reduces fueling and delays migration in songbirds. Science 365:1177-1180. https://doi.org/10.1126/ science.aaw9419

Erskine, A. J. 1971. Some new perspectives on the breeding ecology of Common Grackles. Wilson Bulletin 352-370.

Eyer, L. E. 1954. A life-history study of the Bronzed Grackle, Quiscalus quiscula versicolor Vieillota. Dissertation. Michigan State College of Agriculture and Applied Science, East Lansing, Michigan, USA.

Fankhauser, D. P. 1971. Annual adult survival rates of blackbirds and starlings. Bird-banding 42:36-42. https://doi.org/10.2307/4511715

Ficken, R. W. 1963. Courtship and agonistic behavior of the Common Grackle, Quiscalus quiscula. Auk 80:52-72. https://doi. org/10.2307/4082583

Fletcher, Jr., R. J., R. R. Koford, and D. A. Seaman, 2006. Critical demographic parameters for declining songbirds breeding in restored grasslands. Journal of Wildlife Management 70:145-157. https://doi.org/10.2193/0022-541X(2006)70[145:CDPFDS]2.0.CO;2

Gardali, T., D. C. Barton, J. D. White, G. R. Geupel. 2003. Juvenile and adult survival of Swainson's Thrush (Catharus Ustulatus) in coastal California: annual estimates using capture-recapture analysis. Auk 120:118-1194.

Gaston, K. J. 2010. Valuing common species. Science 327:154-155. https://doi.org/10.1126/science.1182818

Gibbons, D., C. Morrissey, and P. Mineau. 2015. A review of the direct and indirect effects of neonicotinoids and fipronil on vertebrate wildlife. Environmental Science and Pollution Research 22:103-118. https://doi.org/10.1007/s11356-014-3180-5

Hallmann, C. A., R. P. B. Foppen, C. A. M. van Turnhout, H. de Kroon, and E. Jongejans. 2014. Declines in insectivorous birds are associated with high neonicotinoid concentrations. Nature 511:341-343. https://doi.org/10.1038/nature13531

Hamel, P. B. 1974. Age and sex determination of nestling Common Grackles. Bird-banding 45:16-23. https://doi. org/10.2307/4511995

Heisterberg, J. F., A. R. Stickley, Jr., K. M. Garner, and P. D. Foster, Jr. 1987. Controlling blackbirds and starlings at winter roosts using PA-14. Eastern Wildlife Damage Control Conference 3:177-183. University of Nebraska - Lincoln, Lincoln, Nebraska, USA. [online] URL: https://digitalcommons.unl.edu/ewdcc3/22
Holm, G. O., T. J. Hess, D. Justic, L. McNease, R. G. Linscombe, and S. A. Nesbitt. 2003. Population recovery of the eastern Brown Pelican following its extirpation in Louisiana. Wilson Bulletin 115:431-437. https://doi.org/10.1676/03-019

Howe, H. F. 1976. Egg size, hatching asynchrony, sex, and brood reduction in the Common Grackle. Ecology 57:1195-1207. https://doi.org/10.2307/1935044

Howe, H. F. 1977. Sex-ratio adjustment in the Common Grackle. Science 198:744-746. https://doi.org/10.1126/science.198.4318.744

Howe, H. F. 1978. Intial investment, clutch size, and brood reduction in the Common Grackle (Quiscalus quiscula L.). Ecology 59(6):1109-1122. https://doi.org/10.2307/1938226

Howell, A. H. 1911. Birds of Arkansas. U.S. Department of Agriculture, Biological Survey Bulletin 38. USDA, Washington, D.C., USA.

Humann-Guilleminot, S., S. Clément, J. Desprat, Ł. J. Binkowski, G. Glauser, and F. Helfenstein. 2019. A large-scale survey of House Sparrows feathers reveals ubiquitous presence of neonicotinoids in farmlands. Science of the Total Environment 660:1091-1097. https://doi.org/10.1016/j.scitotenv.2019.01.068

Jones, H. P. 1969. The Common Grackle: a nesting study. Kentucky Warbler 45:3-8.

Jones, T. M., T. J. Benson, and M. P. Ward. 2020a. Does the size and developmental stage of traits at fledging reflect juvenile flight ability among songbirds. Functional Ecology 34:799-810. https:// doi.org/10.1111/1365-2435.13513

Jones, T. M., J. D. Brawn, I. J. Ausprey, A. C. Vitz, A. D. Rodewald, D. W. Raybuck, T. J. Boves, C. J. Fiss, D. J. McNeil, S. H. Stoleson, J. L. Larking, W. A. Cox, A. C. Schwarzer, N. P. Horsley, E. M. Trumbo, and M. P. Ward. 2020b. Parental benefits and offspring costs reflect parent-offspring conflict over the age of fledging among songbirds. Proceedings of the National Academy of Sciences 117: 30539-30546. https://doi.org/10.1073/pnas.2008955117

Jones, T. M., J. D. Brawn, and M. P. Ward. 2017. Post-fledging habitat use in the Dickcissel. Condor: Ornithological Applications 119:497-504. https://doi.org/10.1650/CONDOR-17-21.1

Jones, T. M., and M. P. Ward. 2020. Pre- to post-fledging carryover effects and the adaptive significance of variation in wing development for juvenile songbirds. Journal of Animal Ecology 89:2235-2245. https://doi.org/10.1111/1365-2656.13285

Kershner, E. L., J. W. Walk, and R. E. Warner. 2004. Postfledging movements and survival of juvenile Eastern Meadowlarks (Sturnella magna) in Illinois. Auk 121:1146-1154. https://doi. org/10.1093/auk/121.4.1146

Law, R. 1979. Optimal life histories under age-specific predation. American Naturalist 114:399-417. https://doi.org/10.1086/283488

Linz, G. M., M. L. Avery, and R. A. Dolbeer. 2017. Ecology and Management of blackbirds (Icteridae) in North America. CRC Press, Boca Raton, Florida, USA. https://doi.org/10.4324/9781315156439 
Long, C. A., and C. F. Long. 1968. Comments on reproduction of the Common Grackle in central Illinois. Wilson Bulletin, 80 (4):493-494.

Maddox, J. D., and P. J. Weatherhead. 2008. Egg size variation in birds with asynchronous hatching: is bigger really better? American Naturalist 171:358-365. https://doi.org/10.1086/527500

Maddox, J. D., and P. J. Weatherhead. 2009. Seasonal sex allocation by Common Grackles? Revisiting a foundational study. Ecology 90:3190-3196. https://doi.org/10.1890/08-2180.1

Marra, P. P., E. B. Cohen, S. R. Loss, J. E. Rutter, and C. M. Tonra. 2015. A call for full annual cycle research in animal ecology. Biology Letters 11:20150552. https://doi.org/10.1098/rsbl.2015.0552

Martin, T. E. 2004. Avian life-history evolution has an eminent past: does it have a bright future? Auk 121:289-301. https://doi. org/10.1093/auk/121.2.289

Martin, T. E. 2015. Age-related mortality explains life history strategies of tropical and temperate songbirds. Science 349:966-970. https://doi.org/10.1126/science.aad1173

Marzluff, J. M., R. B. Boone, and G. W. Cox. 1994. Historical changes in populations and perceptions of native pest bird species in the West. Studies in Avian Biology 15:202-220.

Maxwell, G. R. 1970. Pair formation, nest building, and egg laying of the Common Grackle in northern Ohio. Ohio Journal of Science 70:284-291. [online] URL: https://kb.osu.edu/handle/1811/5559

Maxwell, G. R., and L. S. Putnam. 1972. Incubation, care of young, and nest success of the Common Grackle (Quiscalus quiscula) in northern Ohio. Auk, 89(2):349-359.

Meanley, B. 1971. Blackbirds and the southern rice crop. US Bureau of Sport Fisheries and Wildlife. U.S. Government Printing Office, Washington, D.C., USA. [online] URL: https:// pubs.er.usgs.gov/publication/rp100

Morrissey, C. A., P. Mineau, J. H. Devries, F. Sanchez-Bayo, M. Liess, M. C. Cavallaro, and K. Liber. 2015. Neonicotinoid contamination of global surface waters and associated risk to aquatic invertebrates: a review. Environment International 74:291-303. https://doi.org/10.1016/j.envint.2014.10.024

Naef-Daenzer, B., and M. U. Grüebler. 2016. Post-fledging survival of altricial birds: ecological determinants and adaptation. Journal of Field Ornithology 87:227-250. https://doi. org/10.1111/jofo. 12157

Nawrocki, J. A., R. L. Schooley, and M. P. Ward. 2019. When good animals love restored habitat in bad neighborhoods: ecological traps for eastern cottontails in agricultural landscapes. Biodiversity and Conservation 28:953-973. https://doi.org/10.1007/ s10531-019-01704-z

Newton, I. 2004. The recent declines of farmland bird populations in Britain: an appraisal of causal factors and conservation actions. Ibis 146:579-600. https://doi.org/10.1111/ j.1474-919X.2004.00375.X

North American Bird Conservation Initiative (NABCI). 2014. The state of the birds 2014. Cornell Lab of Ornithology, Cornell
University, Ithaca, New York, USA. [online] URL: https:// archive.stateofthebirds.org/state-of-the-birds-2014-report/

North American Bird Conservation Initiative (NABCI). 2019. The state of the birds 2019. Cornell Lab of Ornithology, Cornell University, Ithaca, New York, USA. [online] URL: https://www. stateofthebirds.org/2019/

Oli, M. K., and B. Zinner. 2001. Partial life cycle analysis: a model for pre-breeding census data. Oikos 93:376-387. https://doi. org/10.1034/j.1600-0706.2001.930303.x

Pardieck, K. L., D. J. Ziolkowski Jr, M. Lutmerding, V. Aponte, and M. A. R. Hudson. 2019. North American breeding bird survey dataset 1966-2016, version 2018.0. US Geological Survey, Patuxent Wildlife Research Center, Laurel, Maryland, USA.

Peck, G. K., and R. D. James. 1987. Breeding birds of Ontario: nidiology and distribution. Vol. 2. Passerines. Royal Ontario Museum, Toronto, Ontario, Canada.

Peer, B. D., and E. K. Bollinger. 1997. Explanations for the infrequent cowbird parasitism on Common Grackles. Condor 99:151-161. https://doi.org/10.2307/1370233

Peer, B. D., and E. K. Bollinger. 2020. Common Grackle (Quiscalus quiscula), version 1.0. In A. F. Poole and F. B. Gill, editors. Birds of the world. Cornell Lab of Ornithology, Ithaca, New York, USA. https://doi.org/10.2173/bow.comgra.01

Peterjohn, B. G., and J. R. Sauer. 1999. Population status of North American grassland birds from the North American breeding bird survey. Studies in Avian Biology 19:27-44.

Peterjohn, B. G., J. R. Sauer, and W. A. Link. 1994. The 1992 and 1993 summary of the North American breeding bird survey. Bird Populations 2:46-61.

Petersen, A., and H. Young. 1950. A nesting study of the Bronzed Grackle. Auk 67:466-476. https://doi.org/10.2307/4081087

R Core Team. 2018. R: a language and environment for statistical computing. R Foundation for Statistical Computing, Vienna, Austria. [online.] URL: https://www.R-project.org/

Raim, A. 1978. A radio transmitter attachment for small passerine birds. Bird-banding 49:326-332. https://doi.org/10.2307/4512391

Reznick, D. A., H. Bryga, and J. A. Endler. 1990. Experimentally induced life-history evolution in a natural population. Nature 346:357-359. https://doi.org/10.1038/346357a0

Richter, W. 1983. Balanced sex ratios in dimorphic altricial birds: the contribution of sex-specific growth dynamics. American Naturalist 121(2):158-171. https://doi.org/10.1086/284048

Ricklefs, R. E. 1969. An analysis of nesting mortality in birds. Smithsonian contributions to zoology 1-48. https://doi org/10.5479/si.00810282.9

Ridgway, R. 1889. The ornithology of Illinois. H. W. Rokker, Springfield, Illinois, USA.

Robinson, S. K., F. R. Thompson, T. M. Donovan, D. R. Whitehead, and J. Faaborg. 1995. Regional forest fragmentation and the nesting success of migratory birds. Science 267:1987-1990. https://doi.org/10.1126/science.267.5206.1987 
Rosenberg, K. V., A. M. Dokter, P. J. Blancher, J. R. Sauer, A. C. Smith, P. A. Smith, J. C. Stanton, A. Panjabi, L. Helft, M. Parr, and P. P. Marra. 2019. Decline of the North American avifauna. Science 366:120-124. https://doi.org/10.1126/science.aaw1313

Rushing, C. S., J. A. Hostetler, T. S. Sillett, P. P. Marra, J. A. Rotenberg, and T. B. Ryder. 2017. Spatial and temporal drivers of avian population dynamics across the annual cycle. Ecology 98(11):2837-2850. https://doi.org/10.1002/ecy.1967

Sanner, M. F. 1999. Python: a programming language for software integration and development. Journal of Molecular Graphics and Modeling 17:57-61.

Sæther, B. E. and Ø. Bakke. 2000. Avian life history variation and contribution of demographic traits to the population growth rate. Ecology 81(3):642-653. https://doi.org/10.2307/177366

Sauer, J. R., K. L. Pardieck, D. J. Ziolkowski, Jr., A. C. Smith, M.-A. R. Hudson, V. Rodriguez, H. Berlanga, D. K. Niven, and W. A. Link. 2017. The first 50 years of the North American breeding bird survey. Condor: Ornithological Applications 119:576-593. https://doi.org/10.1650/condor-17-83.1

Shaffer, T. L. 2004. A unified approach to analyzing nest success. Auk 121:526-540. https://doi.org/10.1093/auk/121.2.526

Sillett, T. S., and R. T. Holmes. 2002. Variation in survivorship of a migratory songbird throughout its annual cycle. Journal of Animal Ecology 71:296-308. https://doi.org/10.1046/

j.1365-2656.2002.00599.x

Smith, G. J. 2013. Bird Banding Laboratory: an integrated scientific program supporting research and conservation of North American birds. United States Geological Survey, Washington, D.C., USA. https://doi.org/10.3133/ofr20131238

Snelling, J. C. 1968. Overlap in feeding habits of Red-winged Blackbirds and Common Grackles nesting in a cattail marsh. Auk 85:560-585. https://doi.org/10.2307/4083366

Sperry, J. H., R. G. Peak, D. A. Cimprich, and P. J. Weatherhead. 2008. Snake activity affects seasonal variation in nest predation risk for birds. Journal of Avian Biology 39:379-383. https://doi. org/10.1111/j.0908-8857.2008.04451.X

Sperry, J. H., M. P. Ward, and P. J. Weatherhead. 2013. Effects of temperature, moon phase, and prey on nocturnal activity in ratsnakes: an automated telemetry sturdy. Journal of Herpetology 47: 105-111. https://doi.org/10.1670/11-325

Stanton, R. L., C. A. Morrissey, and R. G. Clark. 2018. Analysis of trends and agricultural drivers of farmland bird declines in North America: a review. Agriculture, Ecosystems and Environment 254:244-254. https://doi.org/10.1016/j.agee.2017.11.028

Suedkamp Wells, K. M., M. R. Ryan, J. J. Millspaugh, F. R. Thompson, III, and M. W. Hubbard. 2007. Survival of postfledging grassland birds in Missouri. Condor 109:781-794. https://doi.org/10.1093/condor/109.4.781

Tordoff, H. B., and P. T. Redig. 1997. Midwest Peregrine Falcon demography, 1982-1995. Journal of Raptor Research 31:339-346.

Trautman, M. B. 1940. The birds of Buckeye Lake, Ohio. University of Michigan Press, Ann Arbor, Michigan, USA.
Tucker, G. M., and M. F. Heath. 1994. Birds in Europe: their conservation status. BirdLife International (Conservation Series No. 3). Birdlife International, Cambridge, United Kingdom.

Turner, II, B. L., E. F. Lambin, and A. Reenberg. 2007. The emergence of land change science for global environmental change and sustainability. Proceedings of the National Academy of Sciences 104:20666-20671. https://doi.org/10.1073/pnas.0704119104

Twedt, D. J. 2011. Common grackle breeding on bottomland forest restoration sites. Southeastern Naturalist 10(1):1-10.

United States Department of Agriculture (USDA). 2009. Program data report G - animals taken by wildlife services - FY 2009. United States Department of Agriculture, Washington, D. C., USA. [online] URL: https://www.aphis.usda.gov/wildlife_damage/ prog_data/2009_prog_data/PDR_G_FY09/Basic_Tables_PDR_G/ Table_G_FY2009_Short.pdf

United States Fish and Wildlife Service (USFWS). 2016. Species status assessment report for the Black-capped Vireo (Vireo atricapilla). July 29, 2016 Version 2.0, revised March 2018. Arlington, Texas Ecological Services Field Office, U.S. Fish and Wildlife Service, Arlington, Texas, USA. [online] URL: https:// ecos.fws.gov/ServCat/DownloadFile/157101

VanBeek, K. R., J. D. Brawn, and M. P. Ward. 2014. Does no-till soybean farming provide any benefits for birds? Agriculture, Ecosystems and Environment 185:59-64. https://doi.org/10.1016/ j.agee.2013.12.007

Vander Haegen, W. M., M. A. Schroeder, and R. M. DeGraaf. 2002. Predation on real and artificial nests in shrubsteppe landscapes fragmented by agriculture. Condor 104:496-506. https://doi.org/10.1093/condor/104.3.496

Vitz, A. C., and A. M. Rodewald. 2011. Influence of condition and habitat use on survival of post-fledging songbirds. Condor 113:400-411. https://doi.org/10.1525/cond.2011.100023

Ward, M. P., J. H. Sperry, and P. J. Weatherhead. 2013. Evaluation of automated radio telemetry for quantifying movements and home ranges of snakes. Journal of Herpetology 47:337-345. https://doi.org/10.1670/12-018

Ward, M. P., M. Alessi, T. J. Benson, and S. J. Chiavacci. 2014. The active nightlife of diurnal birds: extraterritorial forays and nocturnal activity patterns. Animal Behavior 88:175-184. https:// doi.org/10.1016/j.anbehav.2013.11.024

Ward, M. P., T. J. Benson, J. Deppe, T. J. Zenzal, R. H. Diehl, A. Celis-Murillo, R. Bolus, and F. R. Moore. 2018. Estimating apparent survival of songbirds crossing the Gulf of Mexico during autumn migration. Proceedings of the Royal Society B 285:20181747. https://doi.org/10.1098/rspb.2018.1747

White, G. C., and K. P. Burnham. 1999. Program MARK: survival estimation from populations of marked animals. Bird Study 46: S120-S139. https://doi.org/10.1080/00063659909477239

Wiens, J. A. 1965. Behavioral interactions of Red-winged Blackbirds and Common Grackles on a common breeding ground. Auk 82:356-374. https://doi.org/10.2307/4083118

Will, T., J. C. Stanton, K. V. Rosenberg, A. O. Panjabi, A. Camfield, A. Shaw, W. E. Thogmartin, and P. J. Blancher. 2019. 
Handbook to the Partners in Flight population estimates database. Version 3.0 (No. 7). Partners in Flight and Bird Conservancy of the Rockies, McAllen, Texas, USA.

Willson, M. F., R. D. St. John, R. J. Lederer, and S. J. Muzos. 1971. Clutch size in grackles. Bird-Banding 42:28-35. https://doi. org/10.2307/4511714

Young, H. 1963. Age-specific mortality in the eggs and nestlings of blackbirds. Auk 80:145-155. https://doi.org/10.2307/4082558

Zhao, Q., and Y. Sun. 2018. Nest-site characteristics and nesting success of the Chestnut Thrush. Ornithological Science 17:3-9. https://doi.org/10.2326/osj.17.3

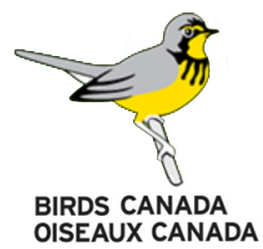

